\title{
Geospatial analysis of shoreline and land use/land cover changes through remote sensing and GIS techniques
}

\author{
Sailesh Samanta ${ }^{1} \cdot$ Saikat Kumar Paul $^{2}$
}

Received: 6 June 2016/Accepted: 13 June 2016/Published online: 20 June 2016

(C) Springer International Publishing Switzerland 2016

\begin{abstract}
This current study was conducted to establish the temporal changes of coastline/shoreline and coastal land use/land cover along the coastal tract between the borders of Orissa to the Jaldha Mouza of Digha Development Planning Area. Digha is most attractive coastal holyday spot in Purba Medinipur district of West Bengal. The area is currently under the threat of coastal erosion caused by sea wave resulting coastline/shoreline shifting. The study finds out the Changes in coastal Land use/land cover and also the nature and characteristics of coastal zone of Digha planning area for management and development of tourism activity. As the population pressure is increasing rapidly the construction and development of settlement are also growing, is another reason of land use/land cover changes. Satellite images of 1990 and 2002 and topographical map of 1972 were used to analyse shoreline shifting of the study area. Major land use/land cover classes were derived from four satellite images (1973, 1990, 2000 and 2002) based on supervised classification. A digital change detection analysis was carried out using the classified data sets to find out the nature of changes in the study area. The study indicates that the coastal processes are the major factors behind the erosion and construction of shoreline. The coastline towards the east lied between hotel Seahawk to Digha
\end{abstract}

Sailesh Samanta

rsgis.sailesh@gmail.com

Saikat Kumar Paul

s9paul@gmail.com

1 GIS Section, Department of Surveying and Land Studies, The PNG University of Technology,

Private Mail Bag Lae, Morobe, Papua New Guinea

2 Department of Architecture and Planning, IIT, Kharagpur, West Bengal, India
Mohana (mouth of the Digha river) and towards the west up to New Digha are severally damaged by coastal dune retreat and encroaching of sea respectively. The area in the west of Shankarpur beach and Ramnagar Khal is under deposition and rest of the area on this area is facing erosion. During field investigation all damages, like pockets of erosions on the sea beach and along the constructed sea wall were observed.

Keywords Remote sensing - Geographical information system - Coastal processes - Land use/land cover . Shoreline change

\section{Introduction}

Coast is the zone between the land and sea are generally characterised by sandy or rocky beach. The shoreline can be considered as the border line between land and sea. The coastline or the shoreline is dynamic in nature as a result it changes gradually either towards the sea or to the land. This change is generally caused by several storm and cyclones for an instant or erosion during over the year by coastal processes. Sea level rise due to global warming effect and seismic events are also involved on a specific range of space and time (Schwartz 2005). All these effects in long-term and short-term changes are causing overall changes of geometry in the coastline. The assessment of changing rate of shoreline is very important for researcher, planner and developer for development of new plans, hazard assessment and zoning, erosion and accretion studies, and sediment budgets (Zuzek et al. 2003). Waves generated by sea correspond to the mechanical energy that introduced to the sea water by the pressure of wind. The surface of the sea shows cyclic ups 
and downs as the wave is propagated towards the land (Wiege 1960). Sea waves are characterised by wave height $(\mathrm{H})$, wave length $(\mathrm{L})$ and wave period $(\mathrm{T})$ which are mandatory inputs for the calculation of breaking zone, breaking type and the breaking energy of wave. Wave climate is the expression of measured/observed value related to these parameters of a coastal region (Wiege 1960). Due to the interaction between waves of different height, period and direction, the surface of sea constantly changing mass of crests and troughs. As the sea waves propagate towards the shore (shallow water near the coastline) from deep sea, all parameters like wave height, length, wave period and direction are significantly changes (Dean and Dalrymple 1991). This change in wave character affects the littoral zone. Coastal problems are related to shallow water wave climate which canbe calculated from the characteristics of deep-water waves. Each coastal belt has its unique physical properties like, slope and alignment, bathymetry and water density. Shallow water wave climate are also naturally extremely varied from place to place (Masselink et al. 2003). Waves characteristics can be changed within a few kilometers near the shoreline, but the deep-sea wave climate data remain same in a particular area. Our study area is located in Purba Medinipur district, West Bengal. There is no physical tide gauge station lead us to identify the nearest tide gauge at Sagar Island at the mouth of Hugli River (Paul 2002). Collected information from this station indicates that tidal water ranged from 5 to $6 \mathrm{~m}$ in the spring tide and $1.5 \mathrm{~m}$ or even less in neap tide. In this context it is expected to be between 2 and $4 \mathrm{~m}$ of tidal range in our study area. The shallow water wave generally decrease in their length and a sharp increase in height. As a result wave crest become more peaked until the wave height is $1 / 7$ th of the wave length $(H: L=0.147)$. Once it pass this critical point, the wave become unstable and breaks (Samanta 2014). The line where the wave is breaks is known as the breaking zone. Breaking type is significance to determines the level of turbulence and suspension of sediments within the wave (Koloa and Samanta 2013). Breaking height and wave energy that generated during breaking of wave are the indication of sediments transportation and breaking angle determines the long shore wave direction and to demarcate the zone of erosion or deposition (Niyogi 1970).

\section{Study area and materials}

The study area is lied in the coastal tract of adjoining Bay of Bengal and boarder of West Bengal and Orissa. The coastal area of is located in the Survey of India topographical map sheet No. 73-O/6 and 73-O/10, covering an area of 8752.63 Acres. The longitudinal and latitudinal extension of the study area is $87^{\circ} 29^{\prime} 40^{\prime \prime} \mathrm{E}$ to $87^{\circ} 37^{\prime} 00^{\prime \prime} \mathrm{E}$ and $21^{\circ} 36^{\prime} 50^{\prime \prime} \mathrm{N}$ to $21^{\circ} 30^{\prime} 00^{\prime \prime} \mathrm{N}$ respectively. The average width (north-south) of the area is $2.75 \mathrm{~km}$ and total length (east-west) of $14 \mathrm{~km}$ (Fig. 1).

Different type of satellite images and other collateral data were used for this study. Three optical bands (Near infrared, red and green) with standard false colour combination (SFCC) of four different satellite images were used (Samanta et al. 2012) to find out the coastline shifting, land use/land cover characteristics and their changes during 1973-2002 in the study area. Table 1 shows all variables and their source, data spans that were used to conduct this research.

\section{Methodology}

\section{Shoreline detection}

First of all four multispectral imageries were enhanced following image enhancement techniques, like min-max stretching, histogram stretching and edge detection using Erdas imagine software. The pixels, which are representing shorelines converted to line feature (vector layer) to identify shoreline position using raster to vector conversion tools in ArcGIS. Shoreline was digitized manually from topographical map. There Shoreline information from two multi-temporal images (1990 and 2002) and topographical map (1972) were compared for obtain the shoreline changes.

\section{Land use/land cover}

Remote sensing imagery and ground truth data were used in identifying different land use/land cover features (Pal et al. 2012). Land use/land cover maps have been derived for the years 1973, 1990, 2000, and 2002 using Maximum Likelihood Classifier in ERDAS IMAGINE software. Land use/land cover classes are characterized by shallow water, deep water/sea, inland marshy, wet sand, dry sand, beach area, settlement, uncultivated upland, cultivated open land, cultivated open land and salt marsh. The overall classification accuracy and kappa statistics were $85.00 \%$ and 0.80 respectively in $1973,86.00 \%$ and 0.84 in $1990,88.00 \%$ and 0.86 in 2000 and $91.00 \%$ and 0.88 in 2002. Land cover change is a direct measure of loss or gain of natural habitat. Change detection provides information about longterm, seasonal or shorter changes of land use/land cover (Samanta and Pal 2016). The change information is extracted by comparing two or more images of an area that were acquired at different times. Change detection study was carried out for the years 1973-2002 based on the land use/land cover classes. 


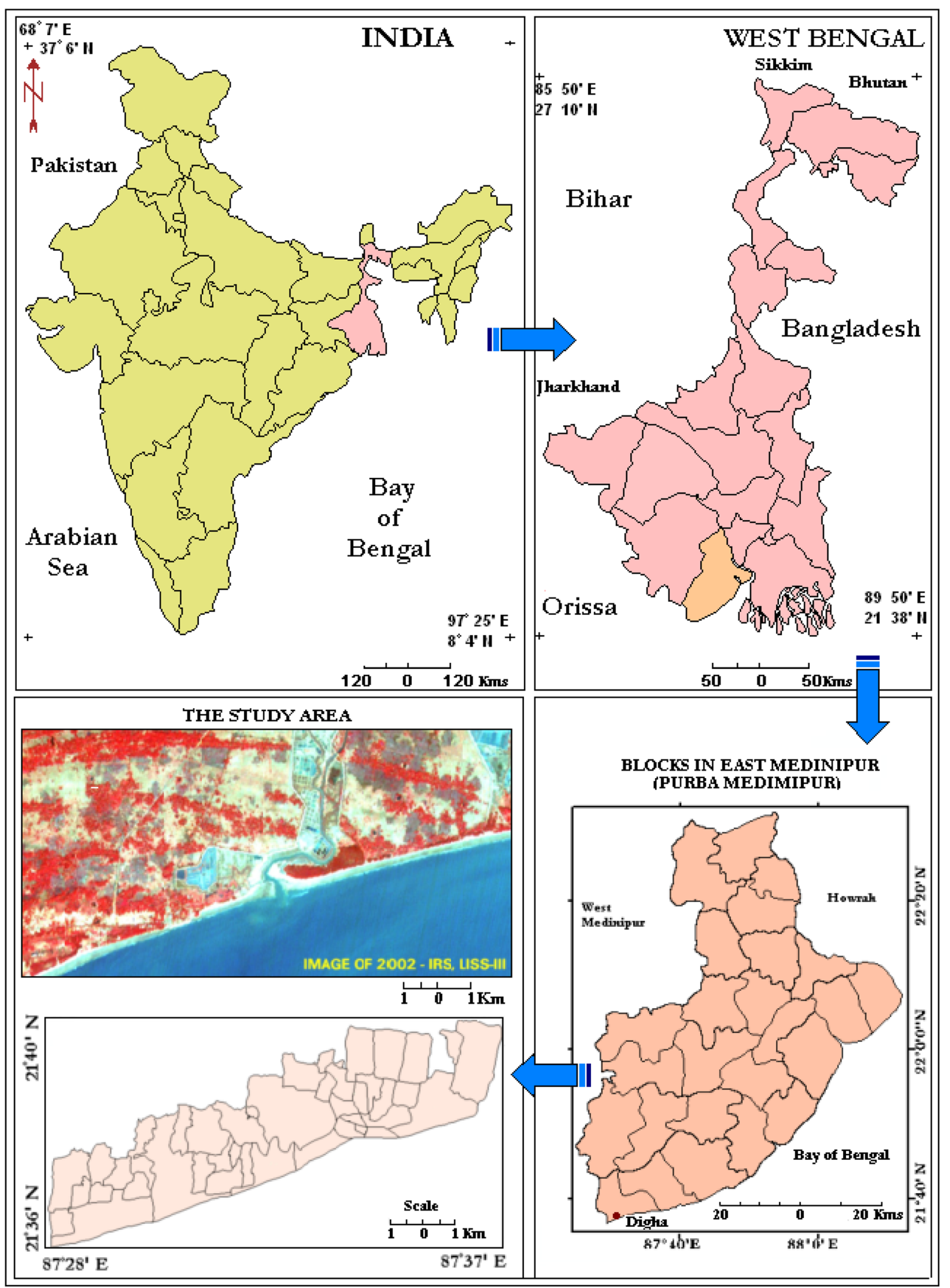

Fig. 1 Location map of the study area 


\section{Breaking zone identification}

To determine the wave breaking zone, different mandatory variables, like dominant deep-sea wave height (Ho), dominant deep-sea wave period $(\mathrm{T})$ were analyzed. These data were varied from one season to another. The deep sea the wave length (Lo) is a function of $\mathrm{T}$ and it was calculated using Eq. 1.

$L_{0}=g T^{2} / 2 \Pi=1.56 T^{2}$

where, $g$ represents the acceleration due to gravity $(9.81 \mathrm{~m} /$ s).

The wavelength (L) changes with different depth conditions (d) while it approaching toward the coastline. The calculation of $d / L o$ was performed using $d / L$ (ratio of depth and wave length at any given depth) as expressed in Eq. 2.

$d / L o=d / L(\tanh ) 2 \Pi(d / L)$

The term $d / L$ is a function $d / L o$ (Shoreline protection manual 1984) was used to calculate $\mathrm{L}$. The change in the $\mathrm{L}$ of an approaching towards the coastline influence the

Table 1 Materials used for the study

\begin{tabular}{|c|c|c|}
\hline Satellite and sensor & Year & Source \\
\hline Landsat-Multi Spectral & $\begin{array}{r}17-01- \\
1973\end{array}$ & \multirow[t]{4}{*}{$\begin{array}{l}\text { Indian Space Research } \\
\text { Organisation, IIT, Kharagpur }\end{array}$} \\
\hline $\begin{array}{l}\text { Landsat-Thematic } \\
\text { Mapper }\end{array}$ & $\begin{array}{r}14-11- \\
1990\end{array}$ & \\
\hline $\begin{array}{l}\text { Landsat-Enhance } \\
\text { Thematic Mapper Plus }\end{array}$ & $\begin{array}{r}15-11- \\
2000\end{array}$ & \\
\hline IRS-LISS III & $\begin{array}{r}04-02- \\
2002\end{array}$ & \\
\hline $\begin{array}{l}\text { Topographical map: } \\
73-\mathrm{O} / 6 \text { and } 73-\mathrm{O} / 10\end{array}$ & 1972 & Vidyasagar University \\
\hline Coastal bathymetric data & 1982 & Naval hydrographic Office, \\
\hline Wave climate data & 2004 & Dehradur \\
\hline
\end{tabular}

changes of the wave height $(\mathrm{H})$. The ratio of $\mathrm{H}$ at any water depth and $\mathrm{Ho}(\mathrm{H} / \mathrm{Ho})$ is function of $\mathrm{d} / \mathrm{Lo}$ was collected from Shoreline protection manual (1984) through Eq. 3 The wave become unstable and breaks when the ration of $\mathrm{H}$ and $d$ pass the critical point $(\mathrm{H} / \mathrm{d}>0.78)$.

$\mathrm{H} / \mathrm{Ho}$

\section{Breaking energy estimation}

Velocity of wave (C) is an indication of the wave characteristics and power that changes the coastal geometry. $\mathrm{C}$ was calculated using the $\mathrm{T}$ and $\mathrm{L}$ function as describe in Eq. 4 .

$C=L / T$

As the wave approaches the low tide line of the beach, the frictional drag applied by the bottom and the wave velocity slows down (Wiegel 1964). The energy that produced during breaking of the wave is a factor of acceleration due to gravity $(\mathrm{g})$, density of salt water $(\mathrm{P})$, wave height $(\mathrm{H})$ and wave length (L) and calculated through Eq. 5.

$E=P g H^{2} L / 8$

\section{Breaking type}

The breaking type is another important parameter that affects the hydrodynamic phenomena of the breaking area. It is the factor of beach slope (m), deep-sea wave height (Ho) and deep-sea wavelength (Lo). There are basically three breaking types are classified based on a classified value (Samanta 2014), namely (i) Spilling ( $\xi_{0}=<0.5$ ), if the wave move up and down without breaking; (ii) Plunging ( $\xi_{0}=0.5-3.3$ ), where the upper crest become steep and fall down the front and (iii) Surging ( $\xi_{0}=>3.3$ ), when the wave front become over steep and plunges to words. The breaking type $\left(\xi_{0}\right)$, was calculated using Eq. 6.
Table 2 Class statistics of Land use/land covers area (in hectors) in different year (1973-2002)

\begin{tabular}{lcccc}
\hline Land use/land cover & Year 1973 & Year 1990 & Year 2000 & Year 2002 \\
\hline Shallow water & 367.92 & 331.11 & 198.1 & 13.91 \\
Deep water/sea & 26.37 & 94.68 & 27.825 & 206.15 \\
Inland marshy & 464.94 & 109.53 & 59.35 & 462.11 \\
Wet sand & 0 & 54.54 & 120.03 & 56.18 \\
Dry sand & 238.59 & 99.72 & 51.21 & 81.52 \\
Beach area & 0 & 146.25 & 271.38 & 238.26 \\
Settlement & 391.68 & 611.28 & 801.59 & 842.01 \\
Uncultivated upland & 342.27 & 668.77 & 622.26 & 470.70 \\
Cultivated land & 1032.5 & 452.16 & 665.27 & 657.76 \\
Vegetation & 124.2 & 241.47 & 384.37 & 215.44 \\
Salt marsh & 437.13 & 596.07 & 208.27 & 165.37 \\
\hline
\end{tabular}




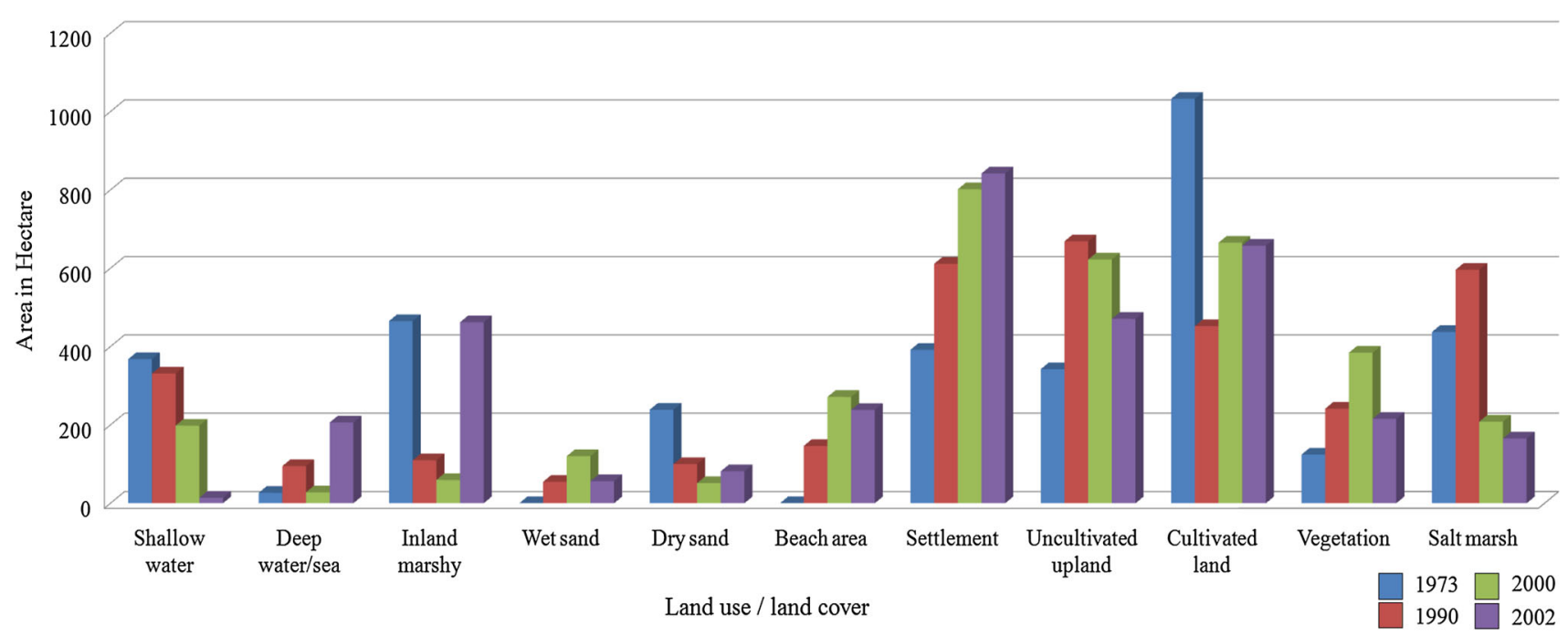

Fig. 2 Land use/land cover statistics during 1973-2002
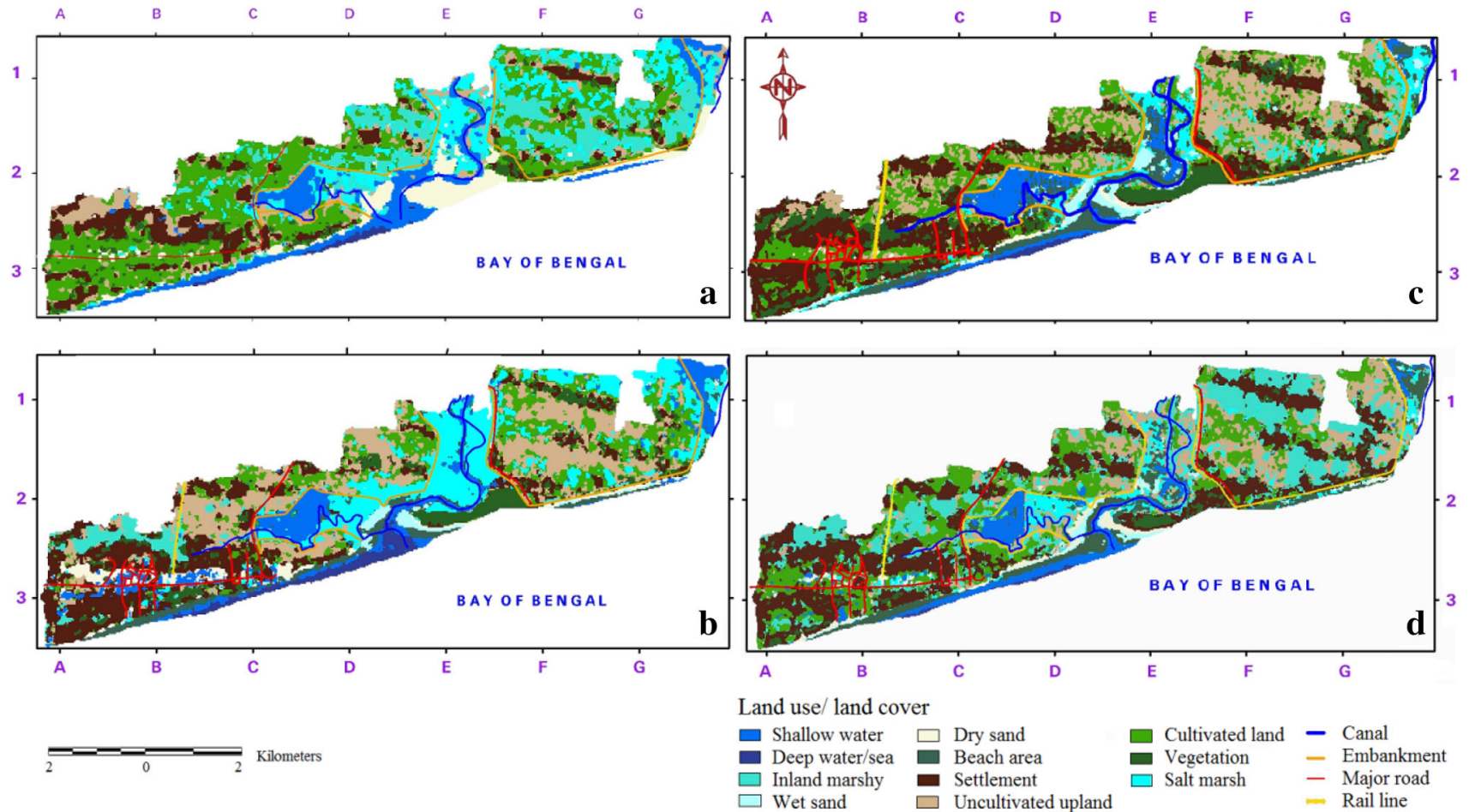

Fig. 3 Land use/land cover classification of 1973 (a), 1990 (b), 2000 (c) and 2002 (d)

$\xi_{0}=\frac{m}{\left(H_{0} / L_{0}\right)^{1 / 2}}$

\section{Result and discussion}

After stratification with the accuracy report, class wise area calculation is performed for each classification. Table 2 and Figs. 2 and 3 shows individual classes with their total area in hector for year 1973-2002. It has been noted that shallow water, salt marsh, cultivated land, dry sand area were decrease while settlement area increased rapidly during 1973-2002.

Figure 4 represents the graphical changes (From and to class) after performing change detection using classification of 2000 and 2002. Areal extent of inland marshy has increased compare to year 2000. Some portions of the cultivated land, uncultivated lands has been converted to the inland marshy and these changes are observed at Jatimati, Padima, Champabani, Khadalgobra, Jagadishpur, Bodhara, Tengamari, Koema, Chandpur \& Jalda mouzas. 
Fig. 4 Change detection of land use/land cover from 2000 to 2002

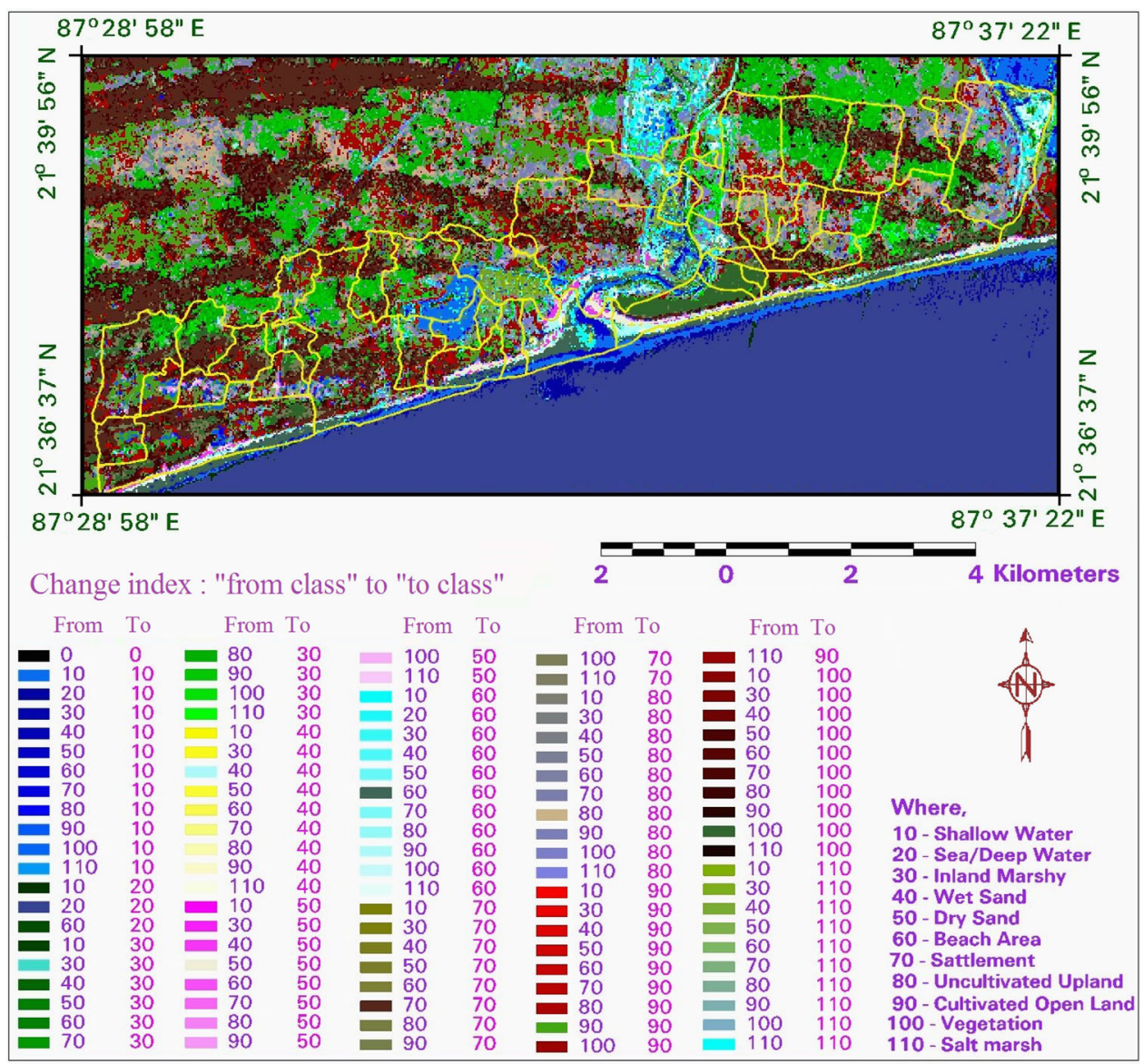

Table 3 Breaking zone identification in different seasons

\begin{tabular}{lcc}
\hline Parameters & $\begin{array}{c}\text { January- } \\
\text { February }\end{array}$ & $\begin{array}{l}\text { June- } \\
\text { July }\end{array}$ \\
\hline $\begin{array}{l}\text { Lo (dominant deep-sea wave height in } \mathrm{m} \text { ) } \\
\text { Ho (the dominant deep-sea wave height in }\end{array}$ & 0.657 & 70.028 \\
m) & & 1.50 \\
T (the dominant deep-sea wave period in s) & 5.86 & 6.70 \\
d (different depth to words the coast line in & 1.00 & 2.00 \\
m) & & \\
d/Lo & 0.0187 & 0.0286 \\
d/L & 0.05611 & 0.07007 \\
L (wave length according to depth to words & 17.822 & 28.543 \\
$\quad$ the coastline in m) & 1.240 & 1.133 \\
H/Ho & & 1.700 \\
H (wave height according to depth to words & 0.815 & \\
the coastline in m) & & 0.850 \\
H/d (critical point to break a wave is 0.78$)$ & 0.8150 & \\
\hline
\end{tabular}

In some areas of Maitrapur, Jagaibasan mouzas, salt marsh is found in the year 2002, whereas in the year 2000 marshy and mainly cultivated land were dominated. Presently coastal sand dunes are gradually migrating land wards, at Begundiha, Atili, Gadadharpur mouzas, and covered some
Table 4 Magnitude of wave breaking energy

\begin{tabular}{lcc}
\hline Parameters & $\begin{array}{l}\text { January- } \\
\text { February }\end{array}$ & June-July \\
\hline d (different depth to words the coast & 1.00 & 2.00 \\
$\quad$ line in m) & & \\
L (wave length according to depth to & 17.822 & 28.543 \\
$\quad$ words the coastline in m) & & \\
C (wave velocity in $\mathrm{m} / \mathrm{s}$ ) & 3.041 & 4.260 \\
H (wave height according to depth to & 0.815 & 1.7 \\
$\quad$ words the coastline in m) & & \\
Acceleration due to gravity (g) & 0.0187 & 0.0286 \\
P (density of salt water in $\mathrm{kg} / \mathrm{m}^{3}$ ) & 1028 & 1025 \\
E (breaking wave energy in $\mathrm{J} / \mathrm{m}$ ) & $14,922.58$ & $103,889.85$ \\
\hline
\end{tabular}

areas of coastal wet sand, cultivated land, salt marsh. Due to increase in population pressure, settlement area has also increased during the recent years. Some uncultivated upland, agricultural land and forest covered area have been converted for settlements. These changes are observed at some places of Khadalgobra, Gangadharpur, Gobindabasan, Dattapur, Padima, Ratanpur, Palsandapur, Baghi baharampur, Shankarpur, Nilpur mouzas. 
Table 5 Angle of wave impact and breaking type in different location

Fig. 5 Shoreline shifting during 1972-2002

\begin{tabular}{llll}
\hline Parameters & New Digha & Old Digha & Shankarpur-Chandpur \\
\hline Angle of wave impact & $5^{\circ} 48^{\prime}$ & $3^{\circ} 3^{\prime} 35^{\prime \prime}$ & $7^{\circ} 42^{\prime}$ \\
M (Beach slope) & $1^{\circ} 13^{\prime} 7^{\prime \prime}$ & $2^{\circ} 34^{\prime} 3^{\prime \prime}$ & $1^{\circ} 52^{\prime} 35^{\prime \prime}$ \\
Breaker type & Spilling & Surging & Spilling \\
\hline
\end{tabular}

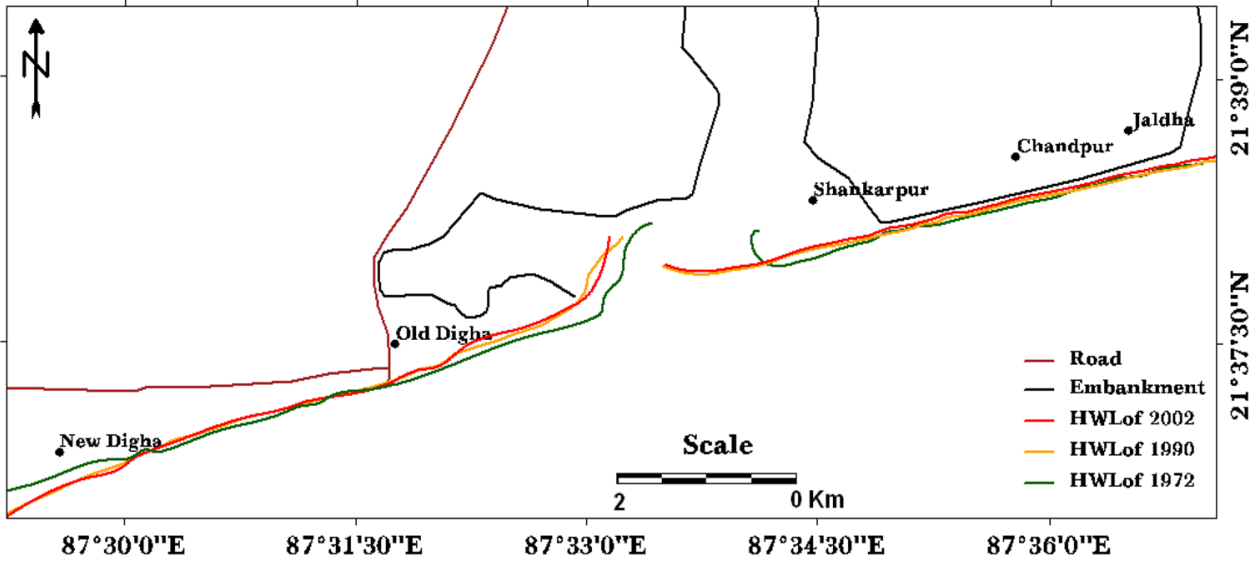

Fig. 6 General land use and coastal vulnerability along the Digha-Chandpur coast

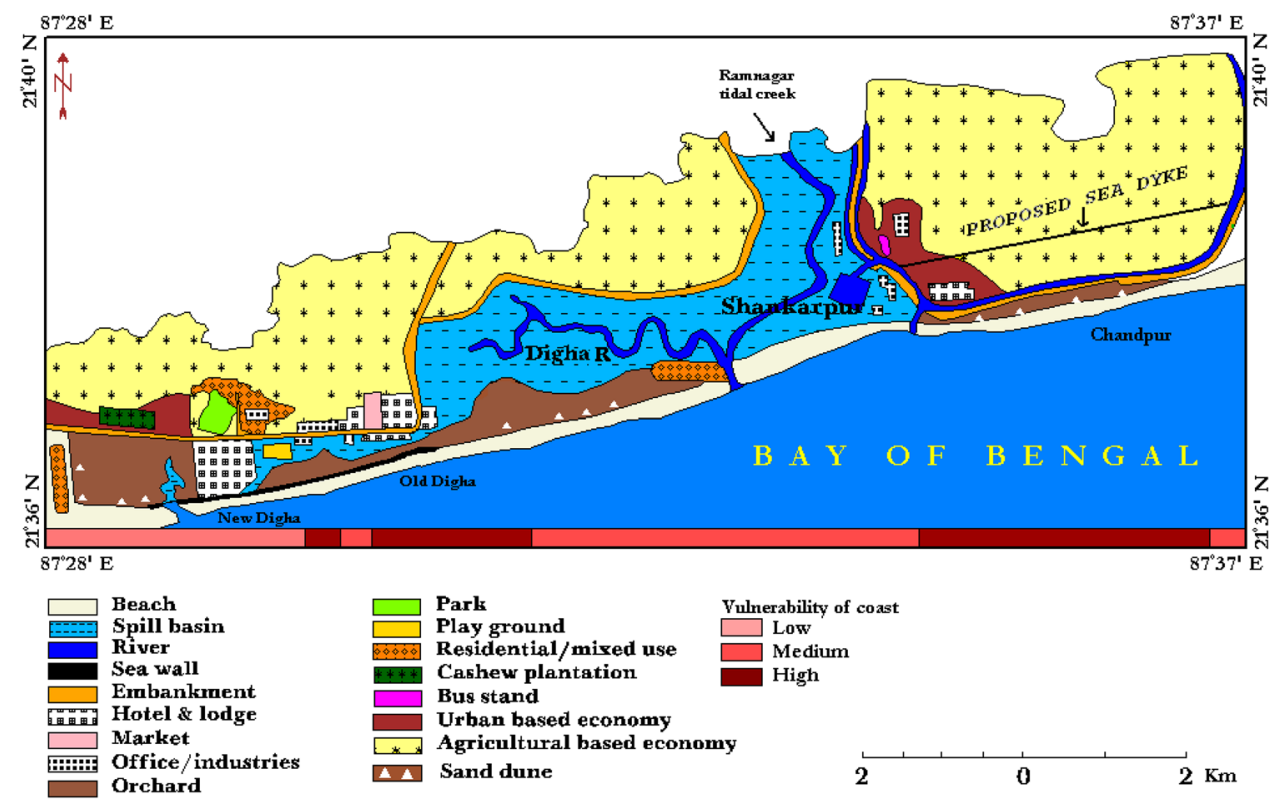

In the month of January and February the Lo, Ho, and T values were estimated $53.570 \mathrm{~m}, 0.657 \mathrm{~m}$ and $5.86 \mathrm{~s}$ respectively (Table 3 ). In the month of June-July value of $\mathrm{Ho}$ is $1.50 \mathrm{~m}, \mathrm{~T}$ is $6.70 \mathrm{~s}$ and Lo was calculated as $70.028 \mathrm{~m}$ and wave breaking zone was found at $2.00 \mathrm{~m}$ depths in compare to $1.00 \mathrm{~m}$ depths in January-February.

The breaking wave velocity during January-February is about $\mathrm{m} / \mathrm{s}$ and in June-July is about $4.260 \mathrm{~m} / \mathrm{s}$. Table 4 shows all functions and their seasonal variations to calculate breaking wave energy. The higher energy in the breaking zone give the indication of erosion and sediment budget of the beach. The speed and energy of the breaking waves are much higher in the rainy season (June-July) than other season throughout the year.

The angle of wave impact, beach slope and breaking wave energy are all together eroding/constructing the beached in the study area. As shown in Table 4, the beach slope is higher in Old Digha $\left(2^{\circ} 34^{\prime} 3^{\prime \prime}\right)$ followed by Shankarpur-chandpur beach $\left(1^{\circ} 52^{\prime} 35^{\prime \prime}\right)$ and New Digha $\left(1^{\circ} 13^{\prime} 7^{\prime \prime}\right)$. On the other hand the angle of wave impact in Shankarpur-Chandpur beach is well very high $\left(7^{\circ} 42^{\prime}\right)$ than New Digha $\left(5^{\circ} 48^{\prime}\right)$ and Old Digha $\left(3^{\circ} 3^{\prime} 35^{\prime \prime}\right)$. During June- 
July during high tide time Old Digha faced Surging breakers, while other place are having spilling breaker (Table 5).

The analysis of shoreline shifting using different satellite images and topographical map proves that there is an average $14 \mathrm{~m} /$ year seaward shifting of coastline in the eastern part of New Digha. This place is under sediment accumulation on the beach and it is marked as low vulnerable (Figs. 5, 6). In Old Digha and Shankarpur-Chandpur the shoreline is shifting with an average rate of $13 \mathrm{~m} /$ year towards the sea. Old Digha is marked as highly vulnerable and ShankarpurChandpur as medium (Figs. 5, 6). In the western part Orissa border to New Digha the vulnerability is much lower than Old Digha and Chandpur section (Samanta and Paul 2008). The vulnerability is moderate in the section between Digha Mohona to Shankarpur (Fig. 6).

\section{Conclusion}

This research proves that changes in land use/land cover and shore line are mainly due to the population pressure and coastal processes. The study demonstrated that the Old Digha is more active in term of erosion activity and damages of constructed seawall. The wave are reaching towards the current position of the embankments with high energy during daily high tide time and eroding the beach. Enormous amount of sand are being thrown into the mid sea causing differences in elevation coastal land and beach at a faster rate. Because of gentle slope in New Digha the spilling breaker could not reach the embankment, so a wide beach is found over there. It is necessary to develop Shankarpur beach, according to the behaviour of the beach. The Shankarpur beach may not be usable from November to April and the clay window becomes exposed from month of May and it is restricted up to Chandpur. Some planning issues that were identified in this study areerosion of Sea Beach, frequent effects of cyclonic storm, corrosion of structure that prevent impact of waves, bad communication system as the mail road is within $50 \mathrm{~m}$ from the sea, development of tourist accommodation near to the sea, inadequate facility for recreation, environmental pollution, lack of sanitary facility, and use of beach as burning ghats or rubbish spot by local and tourist people. So some meaningful action to be considered to protect coastal environment, like-implementation of coastal regulation zone, restriction in further development near the coastline, construction of sea wall along the natural curvature of sea, continuous plantation of low height plants along the coastline, selection of disposal sites, restriction to the fisherman who use the beach for resting their fishing boats and land use provisions in the specific land use zone in the study area. A long-term serious investigations are required to evaluate these relationship between coastline and sub-aerial processes in order to suggest a reasonable management plan for reduction of coastal erosion.

\section{Compliance with ethical standards}

Conflict of interest The authors declare that there is no conflict of interest for the publication of this article.

\section{References}

Dean RG, Dalrymple RA (1991) Water wave mechanics for engineers and scientists. World Scientific, Singapore, pp 1-353. ISBN: 978-9-8102-0420-4

Koloa C, Samanta S (2013) Development impact assessment along Merkham River through remote sensing and GIS technology. Int J Asian Acad Res Assoc 5(1):26-41

Masselink G, Hughes M, Knight J (2003) Introduction to coastal processes and geomorphology, 1st edn. Routledge-Taylor Francis group, USA, pp 1-413. ISBN: 978-1-4441-2240-4

Niyogi D (1970) Geological background of beach erosion at Digha, West Bengal. Bull Geol Min Metall Soc India 43:1-36

Pal B, Samanta S, Pal DK (2012) Morphometric and Hydrological analysis and mapping for Watut watershed using Remote Sensing and GIS techniques. Int J Adv Eng Tech 2(1):357-368

Paul AK (2002) Coastal geomorphology and environment. ABC Publication, Kolkata, pp 1-582. ISBN: 978-8-1875-0011-7

Samanta S (2014) Shoreline change analysis along Hansa and Broken Water Bay coastal tract of Papua New Guinea through remote sensing and GIS. Int J Manag Soc Sci Res 3(11):25-31

Samanta S, Pal DK (2016) Change detection of land use and land cover over a period of 20 years in Papua New Guinea. Nat Sci 8:138-151. doi:10.4236/ns.2016.83017

Samanta S, Paul SK (2008) Effects of coastal processes on shoreline changes along Digha-Shankarpur coastal tract using Remote Sensing and GIS, 29th Asian Conference on Remote Sensing, Colombo, Sri Lanka, 10-14th November, pp 1-11

Samanta S, Pal DK, Lohar D, Pal B (2012) Interpolation of climate variables and temperature modeling. Theor Appl Climatol 107(1):35-45. doi:10.1007/s00704-011-0455-3

Schwartz M (2005) Encyclopedia of coastal science. Springer, Netherlands, pp 1-1097. ISBN: 978-1-4020-4871-5

Wiege RL (1960) Transmission of waves past a rigid vertical thin barrier. J Waterw Harb Div 86(WW1):1-12

Wiegel RL (1964) Oceanographical engineering. Prentice-Hall, New Zealand, pp 1-532. ISBN:978-0-4864-4600-4

Shore Protection Manual (1984) US Army Engineer Waterways Experiment Station, Coastal Engineering Research Center, US Government Printing Office, Washington, DC, 14 (2), pp 587-601

Zuzek PJ, Nairn RB, Thieme SJ (2003) Spatial and temporal consideration for calculating shoreline change rates in the Great Lakes Basin. J Coast Res 38:125-146 